\title{
Seasonal movements of wisents (Bison bonasus L., 1758) in the Bieszczady Mountains (SE Poland)
}

\author{
KAJETAN PERZANOWSKI, MACIEJ JANUSZCZAK and ALEKSANDRA WOŁOSZYN-GAŁĘZA \\ Carpathian Wildlife Research Station, Museum and Institute of Zoology, Polish Academy \\ of Sciences, Ogrodowa 10, 38-700 Ustrzyki Dolne, Poland \\ Corresponding author: Kajetan Perzanowski, StacjaKarpacka@miiz.waw.pl
}

(Received on 18 April 2011; Accepted on 9 November 2011)

\begin{abstract}
We studied seasonal movements of wisents (also known as European bison) from the western subpopulation in the Bieszczady Mountains, in forest districts of Baligród, Komańcza, Lesko, and Cisna. The estimation of distance of seasonal movements was based on telemetric bearings of 4 adult animals (1 cow and 3 bulls) in 2002-2005. We assumed that a maximum distance of movement was a linear extent between 2 most distant locations of an animal recorded in winter and in the following growing season. The maximum distances were 12.8-18.5 km for the cow, and 5.1-22.9 km for bulls. Wisent movements were triggered by significant changes in ambient temperature (decrease in late autumn and increase in early spring) and the appearance of first snowfall in autumn.
\end{abstract}

Keywords: European bison, movements, Carpathians, telemetry, weather factors

\section{INTRODUCTION}

Seasonal migrations of large mammals are frequently observed in all parts of the world. Generally, animals periodically move between winter and summer ranges in search of food, water, and more favourable climatic conditions (BAKER 1978; LIDICKER \& CALDwell 1982). Large-scale migrations are observed in Africa (e.g. blue wildebeest Connochaetes taurinus), North America (e.g. caribou Rangifer tarandus caribou), Asia (e.g. Mongolian gazelle Procapra gutturosa), and may range between several hundred to even over a thousand kilometres (ТАLвот \& TALBOT 1978; LuscheKINA et al. 1985; Bergerud et al. 1990; JiAng et al. 1998; Boone et al. 2006). In Europe, the only large mammals showing at present such a behaviour are Eurasian elk (Alces alces) and reindeer (Rangifer tarandus fennicus) (BERGER 2004; BunNEFELD et al. 2010). One of the reasons is the presence of numerous human-made barriers and a high fragmentation of natural habitats, making long-distance movements very difficult.

Wisents (Bison bonasus), widely known as European bison, are mostly studied in the Białowieża Forest, where due to specific conditions (a majority of optimal hab- 
itats and intensive supplemental feeding in winter inside the extensive forest complex) they are not forced to migrate in search for food. Daily movements recorded there were on average about $0.9 \mathrm{~km}$ in winter and about $0.5 \mathrm{~km}$ in summer. There are several records, however, mostly of solitary bulls, which migrated from their native ranges over distances of several tens to even several hundred kilometres. Such movements, though, can be attributed rather to social factors. Seasonal movements of bulls searching for cows in the rutting season usually do not exceed a few kilometres. Hence, lowland wisents are regarded as a sedentary species (KRASIŃSKA \& KRASIŃSKI 2007; KowALCZYK et al. 2010).

Considerable differences in trophic conditions occur vertically in mountains, where e.g. wapiti (Cervus elaphus nelsoni) are known to migrate seasonally between higher and lower elevations (UNSwORTH et al. 1998). Such movements of wisents were recorded in the Caucasus, before the extirpation of the native population of this species there (KRASIŃSKA \& KRASIŃSKI after KULAGIN 1919).

This paper summarises data on seasonal movements of wisents reintroduced to the wild in the Bieszczady Mountains some 30 years ago, and living there since then almost without human interference.

\section{MATERIALS AND METHODS}

Data for this paper were collected in the lower part of the Bieszczady Mountains (the south-eastern part of Polish Carpathians), west from the road connecting the villages of Lesko and Cisna. This area is inhabited by a free-ranging wisent herd, created as a result of their introduction in the 1980s. At present, this subpopulation is composed of almost 150 individuals distributed over the territory of 4 forest districts: Baligród, Komańcza, Lesko and Cisna (71 250 ha in total), with distinctly different areas of winter and summer concentration (PERZANOwSKi 2009) (Fig. 1). The area is sparsely populated (below 10 inhabitants $/ \mathrm{km}^{2}$ ), and covered mostly (over $85 \%$ ) with forest dominated by beech (Fagus sylvatica) and fir (Abies alba), with admixtures of spruce (Picea abies), grey alder (Alnus incana), sycamore (Acer pseudoplatanus), ash (Fraxinus excelsior), and Scots pine (Pinus sylvestris). The area that now is a part of Natura 2000 site, is situated outside the national park, and is managed by the Regional State Forests Directorate at Krosno.

Telemetric data, used to determine the maximum distance of individual seasonal movements, were obtained by ground triangulation of 4 radio-collared wisents, fitted with MOD-600 Telonix transmitters (151.100-151.240 KHz), from at least 2 bearings taken from different locations in time intervals of 5-10 min, at least twice a week (KERNOHAN et al. 2001). Positions of observers were determined with a GPS receiver (Garmin eTrex Venture) with minimal accuracy estimated at $30 \mathrm{~m}$. For estimates of a home range and kernel analysis in this paper, we used data collected in 2002-2005 (Katajisto \& MoILANEN 2006).

However, periods of seasonal movements were established on the basis of combined data obtained with telemetry, direct observations of animals, and snow tracking in 2005 and 2006, and were compared with average values of monthly temperatures 


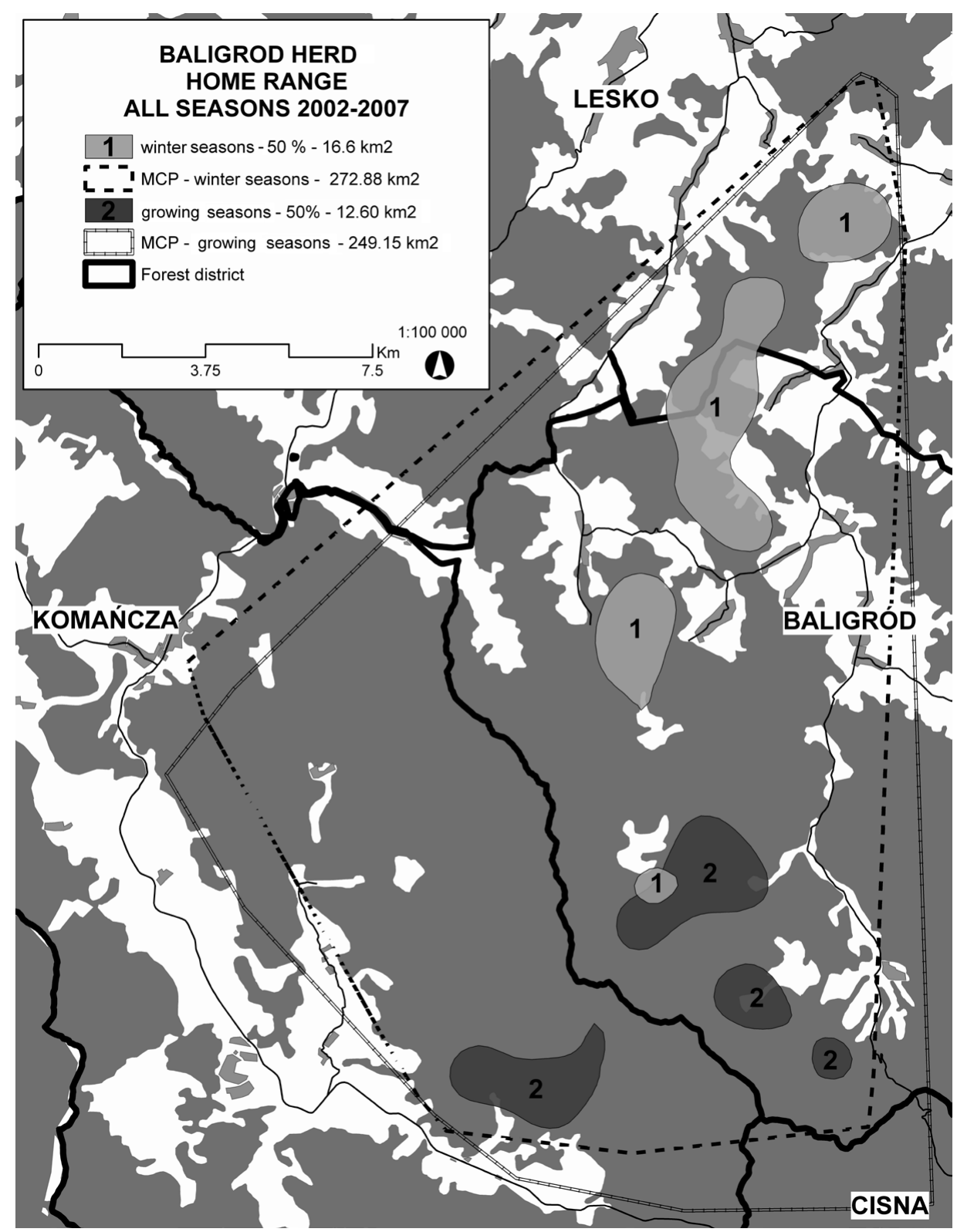

Fig. 1. Winter and summer home ranges of the herd of wisents in the western Bieszczady, estimated on the basis of telemetry data, field tracking, and direct observations. $1=$ areas of winter concentration; 2 = areas of summer concentration; $\mathrm{MCP}=$ seasonal home range as minimal convex polygon. Black triangle and the square indicate geometrical centres of multiannual seasonal concentration areas (summer and winter, respectively) 
and dates of snow fall for the region available for those years from the Institute of Meteorology and Water Management (IMGW).

\section{RESULTS AND DISCUSSION}

A maximum distance of annual movements, estimated as the extent between 2 most distant locations of an animal during winter and summer, only rarely exceeded $20 \mathrm{~km}$ (Table 1). It ranged between 12.8 and $18.5 \mathrm{~km}$ for the cow (mean $\pm \mathrm{SD}$ :

Table 1. Maximum distances $(\mathrm{km})$ measured in 3 consecutive years between the most distant locations of 4 radio-collared wisents from the western subpopulation in the Bieszczady

\begin{tabular}{lllc}
\hline \multirow{2}{*}{ Animal No. } & \multicolumn{3}{c}{ Maximum distance $(\mathrm{km})$ in season } \\
\cline { 2 - 4 } & $2002 / 2003$ & $2003 / 2004$ & $2004 / 2005$ \\
\hline Cow \# 10 & 12.8 & 18.5 & n.d. \\
Bull \# 14 & 12.3 & 14.6 & 12.1 \\
Bull \# 18 & 18.3 & 16.1 & 13.3 \\
Bull \# 24 & 22.9 & 14.1 & 5.1 \\
Average \pm SD & $16.6 \pm 5.01$ & $15.8 \pm 1.98$ & $10.2 \pm 4.45$ \\
\hline
\end{tabular}

n.d. $=$ no data

$15.6 \pm 4.03 \mathrm{~km})$, and between 5.1 and $22.9 \mathrm{~km}$ for bulls $(14.3 \pm 4.85 \mathrm{~km})$. Those figures are lower than data from Białowieża, obtained for dispersing bulls. However, in the Bieszczady population, radio-collared animals were mostly observed accompanying the wild herd, rather than performing long-range movements typical for solitary individuals. Data from the Bieszczady on movement range and home range size are difficult to compare with data on the Białowieża population because of the lack of elevation-related differences in food supply and climatic conditions in the lowland forest and an absence of intensive supplemental winter feeding of wisents in the Bieszczady. Nevertheless, the size of winter home ranges, estimated at Białowieża, were smaller than in the Bieszczady. This can be attributed to the concentration of animals around feeding stations, while summer home ranges were smaller at Bieszczady, probably as an effect of more abundant natural food (PERZANOWSKI \& JANUSZCZAK 2004; KRASIŃSKA \& KRASIŃSKI 2007). Periods of seasonal movements in both analysed years were connected with considerable changes in average monthly temperatures in a few weeks: in spring from the level around $0^{\circ} \mathrm{C}$ to almost $10^{\circ} \mathrm{C}$, and in autumn when temperatures fell below $5^{\circ} \mathrm{C}$. Autumn movements in both years were also well synchronised with the first snowfall, which in this area occurred in late November in 2005 and in late October in 2006 (Fig. 2 a, b).

Therefore, wisents inhabiting the Bieszczady have adapted their behaviour to seasonal fluctuations in food availability and local weather conditions, undertaking movements between their winter and summer ranges of about $13 \mathrm{~km}$ on average. 
$\mathrm{a}$

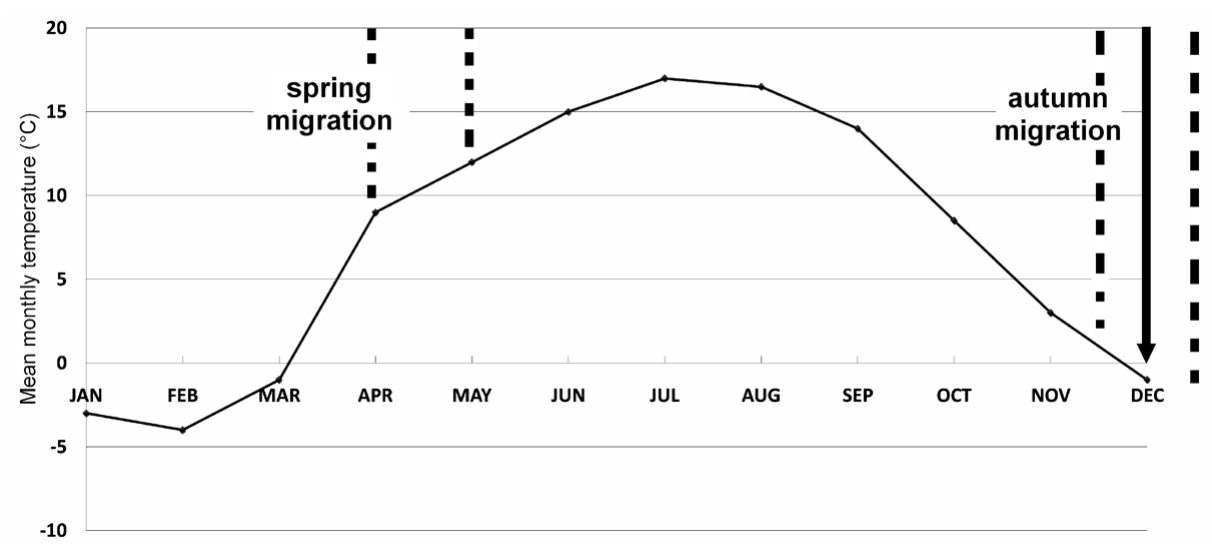

$\mathrm{b}$

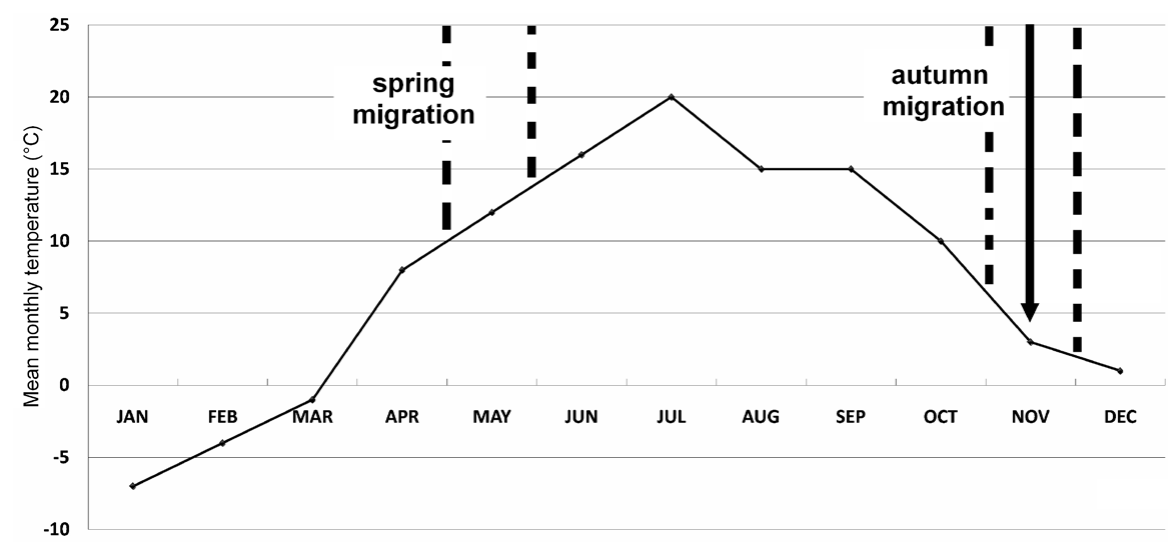

Fig. 2. Periods of seasonal movements of the western subpopulation of wisents in the Bieszczady in 2 consecutive years, compared to changes in average monthly temperature and first snowfall in autumn: $a=2005 ; b=2006$. Vertical arrow indicates the first snowfall in autumn. Broken lines show the period of seasonal movement

The beginning of translocation in spring is triggered by a major increase in monthly temperature, and allows for animals to follow a gradual appearance of new vegetation. The autumn translocation is connected with a decrease in temperature to $0^{\circ} \mathrm{C}$ and the appearance of snow cover in this area. Snow cover has a significant influence upon the availability of natural food, and increases locomotion costs, especially when animals are forced to cross mountain ridges at higher elevations. 
It is disputable whether seasonal movements of wisents in the Bieszczady can be described as migrations, since according to a definition by BERGER (2004), a migration is "a seasonal round trip movement between discrete areas not used at other times of the year". In case of Bieszczady wisents, this is true for a large part of the population, but some animals remain in winter within the summer ranges, and for the whole population the degree of overlap of winter and summer ranges (depicted as minimal convex polygons, MCPs) is very high. Nevertheless, concentration areas of wisents in both seasons can be clearly distinguished, and the distance between geometrical centres for winter and summer concentration areas calculated for multiannual data exceeds $12 \mathrm{~km}$ (Fig. 1). This indicates a dominating tendency for different habitat selection in summer and winter seasons for this population.

Acknowledgements: We thank the Regional Directorate of State Forests at Krosno for assistance in field data collection. We are also grateful to reviewers for their comments, which allowed us to improve the quality of the paper.

\section{REFERENCES}

BAKER R. 1978. The evolutionary ecology of animal migration. Holmes \& Meier Publ., New York. BERGER J. 2004. The last mile: how to sustain long-distance migration in mammals. Conserv. Biol. 18: $320-331$.

Bergerud A. T., Ferguson R., Butler H. E. 1990. Spring migration and dispersion of woodland caribou at calving. Anim. Behav. 39: 360-368.

Boone R. B., Thirgood S. J., Grant J., Hopcraft C. 2006. Serengeti wildebeest migratory patterns modelled from rainfall and new vegetation growth. Ecology 87: 1987-1994.

Bunnefeld N., Börger L., Van Moorter B., Rolandsen C. M., Dettki H., Solberg E. J., Ericsson G. 2010. A model-driven approach to quantify migration patterns: individual, regional and yearly differences. J. Anim. Ecol. 80: 466-476.

Jiang Z., TAKatsuki S., Gao Z., Jin K. 1998. The present status, ecology and conservation of the Mongolian gazelle, Procapra gutturosa: a review. Mammal Study 23: 63-78.

Kataisto J., Moilanen A. 2006. Kernel-based home range method for data with irregular sampling intervals. Ecol. Model. 194: 405-413.

Kernohan B. J., Gitzen R. A., Millspaugh J. J. 2001. Analysis of animals' space use and movement. In: Radio tracking and animal populations (Millspaugh J. J., Marzluff M., Eds.), pp. 125-166, Academic Press, San Diego.

KowalCZyk R., Kamiński T., Schneider T. C. 2010. Wpływ zimowego dokarmiania na żubry w Puszczy Białowieskiej [Effect of winter feeding on European bison in the Białowieża Forest]. In: Ochrona żubra w Puszczy Białowieskiej. Zagrożenia i perspektywy rozwoju populacji [European bison conservation in the Białowieża forest. Threats and prospects of the population development] (KowalczyK R., ŁaWreszuk D., WóJCIK J. M., Eds.), pp. 224, Zakład Badania Ssaków PAN, Białowieża.

KRASiŃSKA M., KRASIŃSKi Z. A. 2007. European bison The Nature Monograph. Białowieża, Mammal Research Institute, Polish Academy of Sience.

Kulagin N. M. 1919. Zubr Belovezhskoi Pushchi. Izdatelstvo Moskovskovo Nauchnogo Instituta, Moskva.

Lidicker W. Z., Caldwell R. L. 1982. Dispersal and migration. Hutchinson Ross Pub. Co., London. 
Luscherina A., Neronov, V., Ogurceva, G., Sokolova, A. 1985. Distribution, ecology, and protection of the Mongolian crop antelope (Procapra gutturosa Pallas 1777). Arch. Nat.schutz Landsch.forsch. 25: 57-69.

PerzanOwSKi 2009. Stały monitoring żubrów na terenie nadleśnictw bieszczadzkich [Permanent monitoring of European bison in forest districts in the Bieszczady Mountains]. Raport I/2009 [Report January 2009]. Regional Directorate of State Forests (RDLP), Krosno.

Perzanowski K., Januszczak M. 2004. Wstępna ocena dynamiki areałów żubrów Bison bonasus w Bieszczadach [Preliminary assessment of the dynamics of ranges of European bison Bison bonasus in the Bieszczady Mountains]. Parki Nar. Rez. Przyr. 4: 639-646.

Тацвот L., Тацвот M. 1978. The wildebeest in western Masailand, East Africa. Wildlife Monographs 12. Allen Press, Kansas.

Unsworth J. W., Kuck, L., Garton, E.O., Butterfield B. R. 1998. Elk habitat selection on the Clearwater National Forest, Idaho. J. Wildl. Manage. 62: 1255-1263. 